Proc. Estonian Acad. Sci. Eng., 2001, 7, 2, 85-98

\title{
HYDRODYNAMICAL AND GEOLOGICAL INVESTIGATIONS OF POSSIBLE DEEP HARBOUR SITES IN NORTH-WESTERN SAAREMAA ISLAND: OVERVIEW AND CONCLUSIONS
}

\author{
Jüri ELKEN ${ }^{\mathrm{a}}$, Jüri KASK ${ }^{\mathrm{b}}$, Tarmo KÕUTS ${ }^{\mathrm{a}}$, Uno LIIV ${ }^{\mathrm{c}}$, Rein PERENS ${ }^{\mathrm{b}}$, and \\ Tarmo SOOMERE ${ }^{\mathrm{a}}$
}

a Estonian Marine Institute, Paldiski mnt. 1, 10317 Tallinn, Estonia; elken@phys.sea.ee
b Estonian Geological Survey, Kadaka tee 82, 12618 Tallinn, Estonia
${ }^{\mathrm{c}}$ Corson Consulting, Akadeemia tee 21 B413, 12618 Tallinn, Estonia

Received 5 April 2001

\begin{abstract}
Saaremaa is the largest Estonian island located to the west of Estonian mainland. A new deep harbour, need for which is stated in the Saaremaa County development plan, is possible only in the north-western part of the island that is environmentally sensitive and belongs partly to the area of Vilsandi National Park. This part of the island is known as wintering area of Steller's Eider and the sanctuary for seals. Environmental impact assessment of the harbour site selection indicated environmental risks at all the considered sites. Discussion of the assessment results led to additional hydrodynamical and geological investigations of the three harbour location alternatives on the Tagamõisa Peninsula: Undva (Uudepanga Bay), Suuriku-Kuriku (entrance of Tagalaht Bay), and Vaigu (central part of Tagalaht Bay). The investigations contained geological and hydrographic field work and modelling of currents and waves. The results revealed that due to dominating cyclonic circulation and small current speeds in the Uudepanga Bay, the risk of oil pollution from the Undva harbour to nearby Vilsandi National Park is rather low. The risk of polluting Steller's Eider wintering area in the north from the harbour site is somewhat higher, but still small. Vaigu has a favourable wave regime, but the bedrock is covered by a sand layer amounting to $10 \mathrm{~m}$ thickness. The waves exceed critical value for sand movement frequently, indicating the need for repeated dredging of ship channels. In addition, contaminant dispersal from Vaigu has the worst pattern. Suuriku-Kuriku has been found the most suitable location for the deep harbour. The expected tough wave regime is not so critical because the high-wave wind directions are rather seldom. As a location of the deep harbour, Undva was found somewhat less favourable and Vaigu considerably less favourable.
\end{abstract}

Key words: Saaremaa Island, harbour, environmental impact assessment, geological setting, currents, waves, oil drift, sediment transport, hydrogeological conditions, modelling. 


\section{INTRODUCTION}

Saaremaa is the largest Estonian island (area $2673 \mathrm{~km}^{2}, 6 \%$ of the whole Estonian territory) located to the west of Estonian mainland. Agricultural land makes $11 \%$, forest $60 \%$, and wetlands $11 \%$ of the total area. From 1944 to 1988 the entire Saaremaa Island was a region restricted for travel and coastal shipping according to the Soviet Union border zone rules. At the same time, several large military bases were located on the island. This made further restrictions to the normal civil life.

Since 1987, when the population of Saaremaa amounted to about 60000 inhabitants, it had decreased to about 40000 in $1997\left[^{1}\right]$. Among them 16500 people were employed in 1998. Tourism is an increasing economic sector and its employment, 1500 persons, has become already comparable with the traditional fishery sector. In 1997 the number of visiting tourists has been estimated 160000 . Saaremaa County has established the main strategic goal as "...developing the tourism industry in combination with rendering services for transit tourists, proceeding from the principles of environmentally friendly and sustainable development" [ $\left.{ }^{1}\right]$. Unique nature of Saaremaa is the main attraction for tourists.

Saaremaa is connected with the Estonian mainland by a $6.1 \mathrm{~km}$ long ferry line Kuivastu-Virtsu that in 2000 passed 285900 vehicles and 869300 passengers [ $\left.{ }^{2}\right]$. The main city of Saaremaa, Kuressaare (about 16000 inhabitants), has a neighbouring harbour Roomassaare. Both bigger harbours, Kuivastu and Roomassaare, can serve the ships with maximum draught not exceeding 4-6 m. Smaller harbours as Veere, Mõntu, Triigi, etc., serve mainly the local fishing fleet.

A new deep harbour is needed for Saaremaa according to the county development plan. The existing harbours have not been designed for contemporary passenger ferries and ro-ro cargo ships. The plan for establishment of the deep harbour has had a big resonance in Estonian society. Besides navigation, logistics and business matters, the most discussed problem has been whether the deep harbour is environmentally acceptable.

The present issue summarizes the scientific results obtained during an intensive 3-month hydrodynamical and geological investigation of the three possible harbour sites. This paper gives an overview and main conclusions of the study.

\section{BACKGROUND OF THE INVESTIGATION}

\subsection{Harbour specification}

The regional development plan of the Saaremaa County $\left[{ }^{3}\right]$ emphasizes that the envisaged deep harbour creates a new dimension for the whole region through integrating it into European transport network and essentially benefits from the increase of industry and tourism.

Saaremaa County administration has established the following principles and parameters of the harbour $\left[{ }^{4,5}\right]$. The harbour must be designed for passenger 
ferries with a possibility to operate ro-ro ships carrying container-based cargo. Cruise ships will frequently visit the harbour. The harbour must have possibility for operating yachts and other small ships. In addition, ships of the border guard and rescue services should be located in the harbour. The harbour must be able to receive ships with following maximum dimensions: length 210 , width 30 , and depth $8.5 \mathrm{~m}$. The harbour must be able to operate with 1500 passengers per day (at least 100 days during a year) and 200000 passengers annually. The harbour must operate up to 500 busses and/or trucks a week and 30000 personal cars annually. To meet those needs, the harbour should consist of three basins: $300 \times 150 \mathrm{~m}$ for large ships (depth $10 \mathrm{~m}$ ), $300 \times 150 \mathrm{~m}$ for medium-size ships (depth $7 \mathrm{~m}$ ), and $200 \times 150 \mathrm{~m}$ for yachts and small ships (depth $3.7 \mathrm{~m}$ ). At least 50 yachts or other small ships must have place within the harbour.

The bays with necessary water depth, exceeding $10 \mathrm{~m}$, are found only in the north-western coast of Saaremaa. It is expected that many of the already existing ferry and cruise lines that pass rather close to the area could make a port call on Saaremaa taking the benefits of tax-free trading.

\subsection{Environmental restrictions to the harbour sites}

The north-western Saaremaa belongs partly to the area of Vilsandi National Park. Legislation excludes this part of the coastline as a harbour location and restrictions cover even larger area.

Saaremaa has a rich flora containing some 1200 plant species, including about 120 rare species with special protection status. As an example, out of the 36 orchid species found in Estonia, 35 are found in Saaremaa and neighbouring islands. Wooded meadows and alvars are beautiful elements of the coastal landscape. Saaremaa has also a variety of rare wildlife species.

Besides local issues, there are at least two international aspects of biodiversity connected with Saaremaa. Firstly, the small islets near the western and southern coasts are permanent resting and breeding areas for a large fraction of grey seal and ringed seal population of the Baltic Sea $\left[^{6}\right]$. Secondly, Saaremaa is an important flyway of migratory birds connecting arctic regions with north-eastern Europe. Hundreds of thousands of birds visit Saaremaa in spring and autumn. Also, remarkable bird colonies use Saaremaa for nesting and wintering. Highest international attention has been paid to the globally endangered Steller's Eider Polysticta stelleri, because considerable part of its global population is wintering in Saaremaa $\left[{ }^{7,8}\right]$. It is an international concern that the planned harbour will not interfere the seals and endangered bird species.

The environmental risks of a harbour consist mainly of the threats appearing during the construction and the exploitation periods. During the construction period, removal and disposal of dredged sediments may cause harm to the marine environment. Each permitted dredging operation must be preceded by an assessment with a concise impact hypothesis describing predicted effects on the physical, chemical, and biological environment $\left[{ }^{9}\right]$. During the harbour exploitation 
oil pollution may occur. For more efficient combating the oil pollution, the countries have to implement oil drift forecast systems $\left[{ }^{10}\right]$. However, ship traffic should be avoided or minimized near environmentally sensitive areas, especially near seabird habitation areas. Several threats originate from ship-generated waves, especially from those by high-speed crafts, in areas with low natural wave activity $\left[{ }^{11}\right]$ including the risk of intensified coastal erosion $\left[{ }^{12}\right]$. Some of the cumulated negative effects of the harbour may appear over some time after the construction. Altering the coastline by the harbour structures may considerably change currents and wave patterns, potentially distorting dynamic balance of sediments in the neighbourhood of the harbour. Consequently, a need for repeated dredging may arise because of filling the ship channels and harbour basins $\left[{ }^{13}\right]$. In addition, negative effects may appear in the groundwater and in the balance of local terrestrial ecosystems.

Within above constraints, three possible harbour sites were selected by the Saaremaa County in $1999\left[{ }^{4}\right]:$ 1) Undva in the eastern coast of the Uudepanga Bay, 2) Veere in the Tagalaht Bay, and 3) Tamme-Ninase in the Küdema Bay. This selection was based partly on earlier investigations $\left[{ }^{14,15}\right]$. A comprehensive environmental impact assessment (EIA) was performed in $1999\left[{ }^{8}\right]$, based on the materials available at this time. The EIA covered present environmental conditions (marine geology, hydrography and meteorology, hydrobiology, fish, birds, coastal dynamics, landscape) and influence of the harbour on different items (protected species and natural objects, fishery, socio-economic aspects). The study also discussed navigation safety problems and measures for combating the marine pollution. However, within the given frames several hydrodynamical and geological aspects were estimated only qualitatively since a solid comparative field study and modelling results were not available.

EIA $\left[{ }^{8}\right]$ revealed unfavourable circumstances at all the considered harbour sites. The Küdema Bay is highly problematic as a harbour site since a number of protected birds are nesting in the neighbourhood Laidu Islet during the summer season. The Uudepanga Bay is most problematic during the cold season because of massive wintering of the globally endangered Steller's Eider Polysticta stelleri. Another risk in the Uudepanga Bay is possible pollution drift to Vilsandi National Park whose marine border is only about $2 \mathrm{~km}$ from the harbour location. Veere in the Tagalaht Bay was found problematic because of relatively shallow and sandy bottom. However, none of the proposed harbour locations was fully excluded. The following recommendations were formulated: 1) the harbour may not be used for oil products, only container cargo should be operated;2) the speed of ships should be limited by 5 knots inside the bays; 3) during the construction period, contemporary technologies minimizing environmental risk must be used; 4) building of housings near the harbour should be avoided; 5) construction of the terrestrial connections must be supervised by competent environmental protection organisations; 6) the harbour owner must finance additional environmental expertise, if necessary, during planning, construction, and running the harbour; 
7) exploitation of the harbour must be periodically audited by competent environmental experts.

The results of EIA stimulated further discussion of the problems of Saaremaa deep harbour. A number of comments is published in $\left[{ }^{16}\right]$.

\subsection{Possible harbour sites and investigation goals}

In the post-EIA discussions, Undva in the Uudepanga Bay stayed on the list, being heavily opposed by several ornithologists. The question whether the accidental oil pollution will spread to the favourable wintering places of Steller's Eider Polysticta stelleri remained. Two alternative sites were proposed in the Tagalaht Bay. Since Veere was found by EIA from the geological and environmental viewpoints unattractive, then an alternative was proposed at Vaigu a few kilometers northward where the bottom depths increase more rapidly but the geological setting of the seafloor was completely unknown. Another alternative harbour location was proposed at Suuriku-Kuriku at the entrance of the Tagalaht Bay in a relatively open coast area. This site raised a question about whether the safety of harbour constructions and navigation can be guaranteed during stronger storms.

Within this background, the Estonian Ministry of Environment ordered comparative hydrodynamical and geological investigations of the three possible deep harbour sites: Undva (Uudepanga Bay, coordinates of the harbour area on the coastline $21^{\circ} 54^{\prime} 33.5^{\prime \prime} \mathrm{E}, \quad 58^{\circ} 30^{\prime} 10.4^{\prime \prime} \mathrm{N}$ and $21^{\circ} 54^{\prime} 49.0^{\prime \prime} \mathrm{E}, 58^{\circ} 30^{\prime} 02.2^{\prime \prime} \mathrm{N}$ ), Suuriku-Kuriku (entrance of Tagalaht Bay, $22^{\circ} 00^{\prime} 18.7^{\prime \prime} \mathrm{E}, 58^{\circ} 30^{\prime} 22.0^{\prime \prime} \mathrm{N}$ and $22^{\circ} 00^{\prime} 33.1^{\prime \prime} \mathrm{E}, 58^{\circ} 30^{\prime} 17.6^{\prime \prime} \mathrm{N}$ ), and Vaigu (eastern coast of Tagamõisa Peninsula, central part of Tagalaht Bay, $22^{\circ} 02^{\prime} 28.7^{\prime \prime} \mathrm{E}, 58^{\circ} 28^{\prime} 17.8^{\prime \prime} \mathrm{N}$ and $22^{\circ} 02^{\prime} 25.1^{\prime \prime} \mathrm{E}$, $\left.58^{\circ} 28^{\prime} 25.7^{\prime \prime} \mathrm{N}\right)$. Both the bays have generally favourable ice conditions. Fast ice is formed only during severe winters and lasts for 20 to 40 days. The map of Tagamõisa Peninsula and the possible harbour sites are given on the inside back cover.

At Undva smooth limestone plateau occurs with very thin or even missing Quaternary cover. The material abraded from Undva cliff is carried mostly eastward and to a lesser extent southward. The original beach ridges made of limestone shingle are poorly preserved, but single low newly formed beach ridges formed during storms are found on the shore. These have formed from the limestone material abraded from the limestone beds exposed on the seafloor. To the 2-m depth contour (about $150 \mathrm{~m}$ from the waterline) occurs shallow limestone plateau. After that, the plateau lowers gradually (forming stairs) to the depth of $7 \mathrm{~m}$. The $10-\mathrm{m}$ depth contour is about $350 \mathrm{~m}$ from the waterline.

Suuriku-Kuriku is located on a relatively flat area between Suuriku and Kuriku cliffs that has a height of 10-12 m. Material of the coastal ridges originates mainly from Suuriku cliff that is abraded by storm waves during high sea level. Abundant cobbles and pebbles are found on the shore and nearshore. The eroded material is carried southward on the nearshore. The seafloor is relatively even, with depths 
increasing smoothly. A 10-m depth contour is found at about $350 \mathrm{~m}$ from the waterline.

At Vaigu, beach ridges occur on the shore, consisting of limestone shingle and pebbles. Abundant cobbles and single boulders are found on the nearshore. The seafloor is mostly even to the 6-m depth contour. After that, the inclination increases. From the 7-m depth contour (about $550 \mathrm{~m}$ from the waterline), there is an escarpment. The $10-\mathrm{m}$ depth contour is about $600 \mathrm{~m}$ from the waterline.

The goal of the study was to establish the most appropriate harbour site by quantitatively addressing the following items: 1) geological and hydrogeological setting on the seafloor and the coast; 2) hydrodynamical (waves, currents, sea level, ice drift) and meteorological factors influencing navigation safety, giving also an indication of hydrodynamical load on the harbour structures; 3 ) influence of the harbour construction works and exploitation on environmental matters like contaminant dispersal and sediment erosion; 4) harbour layout design, wave climate around the berthing quays and navigation routes of the vessels; 5) seabed stability around the proposed harbour structures.

\section{METHODS AND PERFORMED INVESTIGATIONS}

The investigations were conducted in August-November 2000 during a 3-month intensive campaign. A number of different methods of research were used during the study.

Historical meteorological data from Vilsandi (1902-1995), Ristna (19461995), Sõrve (1900-1995), Sõru (1949-1960), and Merise (1949-1963, on the eastern coast of Tagalaht) hydrometeorological stations combined with the results of in situ hydrodynamical, meteorological, geological and hydrogeological measurements were used as the basis for modelling. Among the data used were time series of the wind speed and direction and air pressure from all the measurement sites, and sea level data and (visual) wave parameter recordings at Vilsandi. The wind data were additionally compared with high-resolution measurements at Näsudden (Gotland, 1980-1989). Earlier available information concerning air and surface water temperature, cloudiness, fog, air humidity, ice parameters, and precipitation was generalized for the whole region $\left[{ }^{17-19}\right]$.

During the relatively short but intense measurement campaign, a number of hydrodynamical and meteorological parameters were measured at many different locations. Time series of currents were recorded at three different measurement points next to each possible harbour site using current meters SD6000 (Sensordata A. S.) and RCM7 (Aanderaa Instruments). Vertical profiles of water temperature and salinity were measured at 30 points near harbour sites and over the Tagalaht and Uudepanga bays using CTD probe SEACAT SBE-19 (Sea-Bird Electronics). Horizontal variability of currents due to specific wind regimes was studied on the basis of a number of short-time current measurements with Haamer-type gelatine pendulum current meters $\left[{ }^{17}\right]$. High-resolution time series 
of basic meteorological and wind parameters were recorded during the whole field campaign by an automatic meteorological station (Aanderaa Instruments) mounted at a height of $15 \mathrm{~m}$ from the land (20 m above sea level) at the Undva Cape of Tagamõisa Peninsula. In order to detect and analyse specific wind regime near high cliffs, local wind measurements were performed in the immediate neighbourhood of the possible harbour sites. Pilot survey to determine main wave parameters (wave height and period) was performed by SAIV 204 (A/S Environmental Sensors \& Systems) probe during a few days at harbour sites in quite similar moderate wind conditions $\left[{ }^{19}\right]$.

An extensive campaign of geological and hydrogeological field works was performed in 1999 at Undva and in 2000 at Suuriku-Kuriku and Vaigu. As a first step, geodetic surveying of the coastal zone and detailed bathymetric studies of the harbour sites were performed. Bathymetric surveys were done with echo sounders PC/180 and PEL-3 (Interphase Technologies) using positioning by GARMIN12XL navigator (GARMIN Corporation) including DGPS corrections from the Ristna station. At each site, several drilling experiments clarified the structure and thickness of coastal sediments as well as the structure and depth of bedrock. On the basis of 21 drillholes made on the land with UGB-1VS drilling rig and 6 dynamic probing tests made on the seafloor with floating probing equipment IGT 500, geological cross-sections at Suuriku-Kuriku and Vaigu were constructed. Detailed maps of seafloor sediments were built based on both drilling works and a number of divings. Hydrogeological studies were designed in order to estimate water debit of bedrock, chemical composition of groundwater, and possibilities of using it as a source of drinking or technological water for the harbour. $\left.{ }^{20}\right]$

For modelling of currents, a four-step nested three-dimensional circulation model was used $\left[^{21}\right]$. The coarsest grid of the model covered the whole Baltic Sea area with a grid step $8^{\prime}$ by longitude and $4^{\prime}$ by latitude. One-way nesting using sponge layers at the open boundaries refined each subsequent grid by a factor of

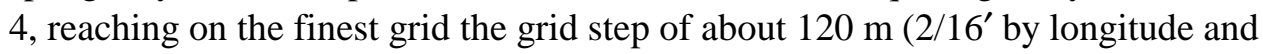
$1 / 16^{\prime}$ by latitude). Because of small grid steps and governing unstratified conditions in the bays of interest, need for computational efficiency dictated a recoding of the Bryan-Cox-Killworth model $\left.{ }^{22}\right]$ for barotropic conditions and implicit timestepping. Horizontal turbulent viscosity coefficient was treated by Smagorinsky shear-dependent formulation. Prescribed constants were used for vertical viscosity in the upper and lower layers. Quadratic bottom drag formulation was used on the seabed. For calibration purposes, the model was forced by actual local wind measurements recorded at Undva Cape whereas down- and upwind fetch dependent wind stress reduction was applied near the coast. With the use of the calibrated model, 32-week long time series of current maps were calculated using data about the wind fields over the Baltic Sea obtained during 1991 by the Swedish Meteorological and Hydrological Institute (SMHI). This wind period was checked to represent the basic long-term statistics of wind speed and direction. Representative model-calculated time series of 
current patterns were used to calculate oil drift probability using Lagrangian particle tracking. A similar method has been earlier applied by SMHI on the request of WWF.

An important part of the research programme formed the analysis of the wind wave regime at open sea and near the harbour sites. This was based on a threestep hierarchy of different models of waves driven by the winds derived from the analysis of the wind regime $\left[{ }^{23,24}\right]$. Firstly, the open sea wave parameters were computed with the use of the third-generation spectral wave model WAM $\left[{ }^{25}\right]$ covering the whole Baltic Sea with a 3-mi grid step. In order to resolve the entrances to the bays of interest, the same model was used in a nested version with a 1-mi grid step allowing estimation of the wave parameters half a grid step (about $1 \mathrm{~km}$ ) from the shore. Basic parameters of the saturated wave fields were computed for constant winds $(15-25 \mathrm{~m} / \mathrm{s})$ of different directions. Since all the harbour sites are closed for southerly winds, only waves generated by west, north, and east winds were estimated. Also, extreme wave parameters corresponding to storms with wind speed about $25 \mathrm{~m} / \mathrm{s}$ were estimated based on directional distribution of extreme wind events $\left[{ }^{18}\right]$. Secondly, transformation of wave properties in the nearshore zone was modelled with the use of the spectral dynamic Near-Shore Wave Model (NSW) from the MIKE 21 software package (Danish Hydraulic Institute). The incoming open sea wave parameters were derived from the WAM results. The periods of dominating waves from both models agreed satisfactorily with direct wave measurements in conditions of moderate winds $\left[{ }^{19}\right]$. Thirdly, behaviour of extreme wave fields close to harbour sites, including the harbour basins, was modelled by the Boussinesq-type wave model BW from the MIKE 21 package $\left[{ }^{24}\right]$. This model resolves behaviour of individual incoming wave patterns. The incoming waves were prescribed by JONSWAP spectrum whose pike period and significant wave height were derived from the NSW results. Prior to the nearshore modelling activities, layouts and first draft of the harbour structures were designed for all the three locations $\left[{ }^{24}\right]$. Finally, sediment transport model SandCalc was used to investigate the critical wave conditions when the bottom particles (sand, shingle), whose parameters were determined from the geological investigations, became unstable and started to move.

\section{OVERVIEW AND DISCUSSION OF THE RESULTS}

Earlier discussions concerning constructing of the new harbour, its possible sites, and its potential dangerous environmental impact have revealed a number of fears and fallacies. The main argument of several environmental experts is that the harbour, if constructed in the Uudepanga Bay, will intensively pollute the territory of Vilsandi National Park. Indeed, the border of the restricted area lies about $2 \mathrm{~km}$ from the harbour site and fast propagation of harbour-related pollution, e.g. oil spills, towards the national park seems a realistic scenario. In 
this way the breeding area of seals located near Kiipsaare Cape might be endangered with high probability. Another argument comes from ornithologists. It says that the harbour at Undva will surely pollute the major wintering area of Steller's Eider located at shallow areas in the southern part of Uudepanga Bay and near Undva Cape $\left[{ }^{8}\right]$. The environmental risk from the Undva harbour was thought to be particularly high because of tough wave regime favouring accidental situations in this area. Uudepanga Bay is indeed open to the northwesterly direction and, by experience, the north-westerly storms are believed to cause ship accidents. The Suuriku-Kuriku site was believed to be highly unsuitable since it is fully open to northerly storms. Additionally, maps published by USSR Ministry of Defence show presence of sand and other fine sediments near Undva and Suuriku-Kuriku and a suitable bottom structure at Vaigu. It was argued that Undva and Suuriku-Kuriku harbours might have regular problems with filling the harbour entrances by eroded fine sediments.

The performed research did not support many of these opinions but also raised some unexpected questions.

Let us consider first some aspects of oil drift that is controlled mainly by currents. Both in situ measurements and numerical experiments clearly demonstrate that currents in the Uudepanga Bay are unexpectedly small. During moderate winds with a speed less than $10 \mathrm{~m} / \mathrm{s}$, the current speeds are fairly below $5 \mathrm{~cm} / \mathrm{s}\left[{ }^{17,21}\right]$. The vector-averaged speed is even less and reaches only about $2 \mathrm{~cm} / \mathrm{s}$ in the harbour area $\left[{ }^{17}\right]$. The currents are directed more frequently to the north. After $24 \mathrm{~h}$ of an accidental oil release it is most probably found at $2 \mathrm{~km}$ to the north, out of the bay, or a bit less probably at $1.5 \mathrm{~km}$ to the south. Consequently, there is enough time to efficiently combat small size oil spills before the pollution reaches Vilsandi National Park or southern coasts of the bay. There is somewhat larger risk to Steller's Eider wintering area located about $3 \mathrm{~km}$ northwards from the harbour site.

In the Tagalaht Bay the current speed is much larger than in the Uudepanga Bay, amounting to $30 \mathrm{~cm} / \mathrm{s}$ at Suuriku-Kuriku and $15 \mathrm{~cm} / \mathrm{s}$ at Vaigu during the winds up to $10 \mathrm{~m} / \mathrm{s}$. The current system has generally a two-layer structure even without density stratification. This pattern favours effective ventilation of the bay and the water is optically very clean. Unexpectedly, the maximum current speed events in both bays are not coherent with the maximum wind speed events. This feature was satisfactorily handled with a nested model $\left[{ }^{21}\right]$ allowing remote forcing of local currents by long water level waves. The nested model approach has also been used for the study of oil spills in the North Sea $\left[{ }^{26}\right]$. Another interesting feature followed from the measurements of wind speed distribution over both bays showing remarkably smaller wind speed near the coasts as compared to the open sea winds. This feature was handled in the model by introducing the fetch-dependent wind stress reduction that improved the match between the measured and modelled currents considerably. We note that without such wind stress reduction we were not able to model such small current speeds in the Uudepanga Bay as were observed in $\left[{ }^{17}\right]$. 
Conditions for possible contaminant dispersion are most favourable at Suuriku-Kuriku. During south-westerly and south-easterly winds the currents detach from the shore due to the coastline curvature and proceed correspondingly to the east and with a smaller speed to the north-west. The structure of currents with persistent winds is relatively stable. After $24 \mathrm{~h}$ of accidental oil release, it is most probably found at $2-4 \mathrm{~km}$ to the south along the coastline, or at 2-4 km to the east towards open waters. Less frequently, the pollution may be found at $2 \mathrm{~km}$ to the west from the coastline $\left[{ }^{21}\right]$. The probability of pollution drift until the Undva Cape, the Steller's Eiders wintering area, is low.

From the viewpoint of the pollution drift, the current patterns are most unfavourable at Vaigu. During south-westerly winds the surface currents may be directed offshore towards eastern coast of the bay. After $24 \mathrm{~h}$ of accidental oil release the pollution may be found on a large area over the bay: alongshore at $4.5 \mathrm{~km}$ to the north, $4 \mathrm{~km}$ to the south or on the $4-\mathrm{km}$ shore segment of the eastern coast of the Tagalaht Bay $\left[{ }^{21}\right]$.

Geological investigations established that the amount of sand and other fine sediments is smaller at Undva and Suuriku-Kuriku harbour sites. The information on the former USSR classified maps was apparently based on randomly scattered small spots of sand. Although the spots cover a certain area, their thickness is only about a few dozens of centimeters. On the contrary, at Vaigu (for which maps show even a less amount of sand than at Undva), geological research established thickness of the sand layer over $10 \mathrm{~m}\left[{ }^{20}\right]$. Generally, breakwaters and quays must be constructed on a solid ground - carbonate bedrock. This means that a $10 \mathrm{~m}$ thick layer of sand must be removed until $15 \mathrm{~m}$ depth at Vaigu. The critical wave heights needed for the sand movement occur frequently $\left[{ }^{24}\right]$ and the dredged sand could spread on the bottom over a large area. The bottom fauna and fish spawning grounds may be harmed for a long period if covered even by noncontaminated sand. In addition, it is highly probable that the harbour entrance must be repeatedly re-dredged.

Although Undva and Suuriku-Kuriku are relatively close to each other and are located in geologically very similar conditions, the resources of fresh groundwater are very much different. At Suuriku-Kuriku, the groundwater is of relatively high quality and the water resources are evidently sufficient for running the harbour. At Undva, the water resources apparently are insufficient and the groundwater is brackish. Thus a serious problem of water supply of the visiting vessels will certainly arise at Undva. At Vaigu, hydrogeological parameters are favourable for constructing and running the harbour $\left[{ }^{20}\right]$.

Wave modelling did not fully confirm our ad hoc assumptions. Surprisingly enough, wave regimes at Undva and Suuriku-Kuriku were not much worse than at well-sheltered Vaigu. Wave heights exceeding $3 \mathrm{~m}$ occur with a probability of $1 \%$ at Undva, $0.6 \%$ at Suuriku-Kuriku, and $0.13 \%$ at Vaigu. This formally indicates that Vaigu has the best wave regime. However, calculations with NSW spectral wave model show that convergence of wave energy, owing to topographic refraction, takes place exactly at Vaigu harbour. Calculated maximum wave 
heights during northerly storms are at Vaigu even larger than at other sites $\left[^{24}\right]$. We note that northerly storms in the area in question are relatively frequent $\left[{ }^{18}\right]$ and may have the largest wind speed $\left[{ }^{27}\right]$.

At first glance it is not easy to interpret the conclusion made in $\left[{ }^{24}\right]$ that wave field within the Suuriku-Kuriku harbour is the mildest among the three analysed locations. South-easterly storms should cause problems both at Vaigu and Suuriku-Kuriku. Most probably, the proposed shape of breakwaters fits well with the particular geometry of the coastline. Also, absence of reflected waves at Suuriku-Kuriku during northerly and north-easterly storms ensures milder wave regime in the harbour basins than at Vaigu where topographic wave energy concentration may cause certain problems. In addition, Ristna Peninsula (Hiiumaa) offers some protection of the harbour against waves generated by northerly winds. Also, strong north-easterly and easterly winds are extremely rare in the whole Baltic Proper $\left[{ }^{27}\right]$.

Further analysis of the modelling results suggests that the seemingly tough wave regime at Undva is actually not that bad. Angular distribution of basic wind parameters (frequency of occurrence of wind events, mean and maximum wind speeds) exhibits a relatively deep minimum for north-west direction in which the Uudepanga Bay is open. Attenuation of wave heights in the coastal zone (about $1 \mathrm{~km}$ from the coastline) is strongest at Undva. Although waves are typically highest (up to $6.5 \mathrm{~m}$ ) near this site, extreme wave loads on the breakwater and wave heights at the harbour entrance are comparable at all the three sites. The wave situation at Undva may become complicated during strong westerly storms accompanied by high sea level. The trapping shallow water area Harilaiu Bank, located north-west from the Kiipsaare Cape, has water depth 1-2 m in normal conditions. For the waves travelling from the west, it serves as a natural breakwater suppressing waves with a height above $3 \mathrm{~m}$. During extreme high water when the sea level exceeds the average value by $1.5 \mathrm{~m}$, higher waves may pass the area and reach the harbour from its unprotected side.

Another unexpected negative feature of Undva harbour site is connected with modelled wave height anomalies in the area of the underwater slope of Harilaiu Bank $\left[{ }^{23,24}\right]$ and Undva Cape $\left.{ }^{24}\right]$. The first anomaly emerges when significant wave height at open sea exceeds $5 \mathrm{~m}$. The wave models predict local wave height increase by about $2 \mathrm{~m}$ as compared to the height of incident waves. The second anomaly at Undva Cape may exist when wave height exceeds $3 \mathrm{~m}$. Location of the high wave area essentially depends on wind speed and direction. Water level and large-scale wind pattern may additionally modify the anomaly. In the model, the anomaly becomes evident already within about $3 \mathrm{~h}$ after a strong storm starts. In many cases, it may be located directly on the ship lane to the Undva harbour. As discussed in $\left[{ }^{23}\right]$, topographically controlled deviation of the wave rays may lead to the emerging of "caustics" where a reflection of the wave energy may occur. Reflected wave energy is radiated with an extremely high wave front preceded by an equally deep trough and followed by a more or less sinusoidal "tail" $\left[{ }^{28}\right]$. Such structures resemble freak (giant waves) and their existence near 
the harbour sites has to be clarified prior to harbour operation. We note that the above discussion on wave anomalies follows from the results of the spectral wave models. No measurements made during strong storms that can support or reject the local wave anomaly hypothesis, are available.

\section{CONCLUSIONS}

The project evaluated possible deep harbour locations in the north-western Saaremaa Island based on the comparative study of hydrodynamical and geological conditions. Three alternative harbour locations were considered: Suuriku-Kuriku near the entrance and Vaigu in the central area of the Tagalaht Bay (both on the western coast of the bay), and Undva on the eastern coast of the Uudepanga Bay.

The performed investigations did not support the opinion, raised in 1999 during discussion of the EIA results, that construction of the harbour at Undva will encounter high risk of oil pollution towards the Steller's Eider wintering areas located in the southern and western coasts of the Uudepanga Bay. Both the measurements and the modelling results revealed small current speeds in the bay. Due to dominating cyclonic circulation pattern, potential oil pollution will be most probably drifted out of the bay along the eastern shore. Probability of polluting the nearby Vilsandi National Park is rather low. The risk of polluting Steller's Eider wintering area in the north from the harbour site is somewhat higher, but still small.

Neither did the investigations support the opinion that wave regime near Suuriku-Kuriku is due to open coastline much tougher than at more sheltered Undva. Suuriku-Kuriku is open for north-easterly winds, but stronger ( $>15 \mathrm{~m} / \mathrm{s}$ ) winds of that direction are rather seldom. The calculated wave heights exceed $3 \mathrm{~m}$ with the following frequency: Suuriku-Kuriku $-0.6 \%$, Vaigu $-0.13 \%$, and Undva $-1 \%$ of days. Undva is somewhat less favourable also because of the possibility of anomalies with locally increased wave height. Vaigu has favourable wave conditions but this is practically the only positive factor of that location.

Suuriku-Kuriku has slight geological and hydrogeological advantages over Undva. Undva is characterized by stronger limestone seabed, but the conditions for retrieving the fresh ground water are more complicated. Vaigu is considered geologically as most unfavourable since the sand layer covering the bedrock amounts to $10 \mathrm{~m}$. Vaigu has also environmental disadvantages since pollution drift occurs over a large area of the bay. Dredging of sand disturbs the seabed dynamic stability since critical wave heights for sand movements occur frequently.

The study gave preference to Suuriku-Kuriku as a location of the deep harbour. Undva was found somewhat less favourable and Vaigu considerably less favourable. 


\section{ACKNOWLEDGEMENTS}

This investigation was ordered and managed by the Estonian Ministry of Environment using the funds from the Estonian Centre of Environmental Investments. Partly this work was supported also by the Estonian Science Foundation (grants No. 4025 and 4171).

\section{REFERENCES}

1. The Development Strategy. Saaremaa Island of Baltic Sea. http://www.saaremaa.ee.

2. Reisijate ja sõidukite üleveo 2000. a. statistiline ülevaade. Saaremaa Laevakompanii AS, 2001. http://www.slk.saaremaa.ee.

3. Saare maakonna planeering. Saare Maavalitsus, Kuressaare, 1999.

4. Pikner, T. Lähteülesanne Saaremaa süvasadama asukohavaliku keskkonnaekspertiisile. Saare Maavalitsus, Kuressaare, 02.08.1999.

5. Saare Maavalitsuse kiri nr. 1-27/845, 30.10.2000.

6. HELCOM, 1996. Nature conservation and biodiversity: Marine mammals. Third periodic assessment of the state of the marine environment of the Baltic Sea, 1989-93. Baltic Sea Environment Proc., 1996, No. 64B.

7. Kullapere, K. and Aumees, M. Kirjuhaha ränne Vilsandi Rahvuspargis ja Loode-Saaremaal. Linnurada, 1997, 1, 24-28.

8. Saaremaa süvasadama asukohavaliku keskkonnamõjude hindamine. Eesti Mereinstituut, Tallinn, 1999.

9. HELCOM. Recommendation $13 / 1$ on disposal of dredged spoils. In Baltic Sea Environment Proc., 1992, No. 42.

10. HELCOM. Recommendation 12/6 on development and use of oil drift forecasting. In Baltic Sea Environment Proc., 1991, No. 37.

11. Environmental Effects of High-speed Craft. Memorandum MECP 44/19 (28.10.1999). International Maritime Organization, London, 1999.

12. Marine Information Note MIN $48(M+F)$ on the Research Project 420: Investigation of High Speed Craft (HSC) on Routes Near to Land or Enclosed Estuaries. Maritime and Coastguard Agency, Southhampton, October, 1999.

13. Taal, J. Rannikumere laevateede haldamine Rohuküla-Heltermaa laevatee näitel. Tallinna Pedagoogikaülikool, Tallinn, 2001.

14. Saaremaa süvasadam. Saaremaa Läänesadama asukoha valik. Merin AS, Tallinn, 1997.

15. Esialgne ekspertarvamus kruiisilaevade sadama asukohast - Undva sadam Uudepanga lahe idarannikul. Merin AS, Tallinn, 1998.

16. Eesti Loodus, 2000, 2/3, 50-63.

17. Kõuts, T. and Laanearu, J. Variability of currents in bays of Tagalaht and Uudepanga. Proc. Estonian Acad. Sci. Eng., 2001, 7, 126-140.

18. Soomere, T. and Keevallik, S. Anisotropy of moderate and strong winds in the Baltic Proper. Proc. Estonian Acad. Sci. Eng., 2001, 7, 35-49.

19. Elken. J., Soomere, T., Kask, J., Kõuts, T., Liiv, U., Perens, R., and Rõõm, R. Saaremaa süvasadama võimalike asukohtade hüdrodünaamilised ja geoloogilised uuringud. Eesti Mereinstituut, Tallinn, 2000.

20. Kask, J., Perens, H., Perens, R., Suuroja, S., and Kask, A. Comparison of geological settings at possible deep harbour sites, north-western Saaremaa Island. Proc. Estonian Acad. Sci. Eng., 2001, 7, 99-125.

21. Elken, J. Modelling of coastal circulation and oil drift in possible deep harbour sites, northwestern Saaremaa Island. Proc. Estonian Acad. Sci. Eng., 2001, 7, 141-156. 
22. Killworth, P., Stainforth, D. D., Webbs, D. J., and Paterson, S. M. A Free Surface Bryan-CoxSemtner Model. Inst. Oceanogr. Sci., Deacon Laboratory, Report No. 270, 1989.

23. Soomere, T. Wave regimes and anomalies off north-western Saaremaa Island. Proc. Estonian Acad. Sci. Eng., 2001, 7, 157-173.

24. Liiv, T. and Liiv, U. Saaremaa deep harbour layout design and computer simulation of the wave climate and sediment transport. Proc. Estonian Acad. Sci. Eng., 2001, 7, 174-192.

25. Komen, G. J., $\quad$ Cavaleri, L., $\quad$ Donelan, M., $\quad$ Hasselmann, K., $\quad$ Hasselmann, S. and Janssen, P. A. E. M. Dynamics and Modelling of Ocean Waves. Cambridge University Press, Cambridge, 1994.

26. Dick, S. and Soetje, K. C. An operational oil dispersion model for the German Bight. Dtsch. Hydrogr. Z., 1990, Ergaenzungsh., No. 16.

27. Soomere, T. Extreme wind regimes and spatially uniform wind events in the Baltic Proper. Proc. Estonian Acad. Sci. Eng. Forthcoming.

28. White, B. S. and Fornberg, B. On the chance of freak waves at sea. J. Fluid Mech., 1998, 355, 113-138.

\title{
LOODE-SAAREMAA SÜVASADAMA VÕIMALIKE ASUKOHTADE HÜDRODÜNAAMILISED JA GEOLOOGILISED UURINGUD: ÜLEVAADE JA KOKKUVÕTE
}

\author{
Jüri ELKEN, Jüri KASK, Tarmo KÕUTS, Uno LIIV, Rein PERENS ja \\ Tarmo SOOMERE
}

Saaremaa süvasadama rajamine on võimalik saare keskkonnatundlikus loodeosas, kus paiknevad kirjuhahkade talvituspiirkonnad ja hüljeste lesilad. Keskkonnamõjude hindamine tõi kõigis vaadeldud kohtades esile keskkonnariskid ja tingis hüdrodünaamilisi ja geoloogilisi lisauuringuid Tagamõisa poolsaarel asuvas kolmes võimalikus sadamakohas: Undva Uudepanga lahe idarannikul, Suuriku-Kuriku Tagalahe suudmes ja Vaigu Tagalahe läänerannikul. Uuringute käigus korraldati geoloogilised ja hüdrograafilised välitööd ning modelleeriti hoovusi ja laineid. Uudepanga lahe tsüklonaalse tsirkulatsiooni ning väikeste hoovuskiiruste tõttu on Vilsandi Rahvuspargi randade õliga reostumine vähetõenäoline. Undva neemel paikneva kirjuhahkade talvituspaiga reostumise oht on mõnevõrra suurem, kuid siiski väike. Vaigu sadamakohas on soodne lainetusrežiim, kuid aluspõhjal paikneb kuni 10 m paksune liivakiht. Setete liikumiseks vajalik kriitiline lainekõrgus esineb sageli, mis viitab laevateede korduvsüvendamise vajadusele. Samuti oleks Vaigu sadamakohas reostusainete levik kõige laialdasem. Parimaks sadamakohaks on Suuriku-Kuriku. Eeldatud halb lainetusrežiim ei ole kriitiline, sest kõrgeid laineid esile kutsuvaid tuulesuundi esineb harva. Undva sadamakoht on mõnevõrra vähem ning Vaigu sadamakoht oluliselt vähem soodne. 